DOI: $\underline{10.35619 / \text { iiu.v1i14.427 }}$

Tetiana Tsipan Candidate of Pedagogical Sciences, Associate Professor, Associate Professor at the Department of Theory and Methods of Education Rivne State University for the Humanities,

Rivne, Ukraine ORCID: 0000-0002-1356-2825 e-mail:23ttss22@ukr.net

\title{
PSYCHOLOGICAL AND PEDAGOGICAL PREVENTION OF BULLYING IN THE SCHOOL ENVIRONMENT
}

\begin{abstract}
The article analyzes the concept of "bullying" and describes the areas of psychological and pedagogical prevention of this phenomenon. Bullying is considered as individual or group physical or psychological violence against a person who is unable to defend himself at the time of the violence against him; as a form of cruel behavior, when the physically or psychologically stronger (bully, abuser) gets pleasure from ridicule, bullying of the weaker (victim). The factors and reasons for the spread of bulling in the school environment are clarified.

Bullying has been found to exist in two behavioral subcategories: direct and indirect bullying. Direct intimidation (active bullying) involves: threats, humiliation, insults, humiliation, harassment, causing trouble; indirect intimidation (passive bullying) includes: spreading rumors, spoiling personal belongings, lying, damaging reputation, isolation. Five stages of bulling were analyzed: creation of conditions, initial stage, active stage, social isolation of the victim, escalation of the conflict.

Factors contributing to the development and spread of bullying in adolescence were identified: low socio-economic status of the family, intrafamily conflicts, changes in the family (the appearance of a stepfather, stepmother, second child, etc.), hyperopia or indifference of parents; low school performance and inflated requirements for students achievement, which do not correspond to their abilities, capabilities; low level of education; self-affirmation by humiliating the victim, up to the satisfaction of their own sadistic needs; alcohol, drug and computer game abuse; the struggle for power in the group, the desire and need to dominate others; life experience, which includes manifestations of aggression, hostility, violence, etc.

It was found that important in the practical activities of the school is the psychological and pedagogical prevention of bullying, which is implemented at the individual, group, school and family levels, and aimed at maintaining the mental health of students, as well as creating conditions that minimize or the
\end{abstract}




\section{Інноватика у вихованні. Випуск 14. 2021.}

influence of factors provoking violence, harassment, aggression, terror, etc. is leveled off.

Keywords: bullying, schoolchildren, diagnostics, psychological and pedagogical prevention.

Target setting. In the system of psychological and pedagogical research, the problem of prevention of antisocial behavior has always been relevant. Modern youth being formed in difficult socio-cultural conditions and instability of social processes, the destructive behavior of minors deepens. That's why disregard for legal, moral, social norms, progressive alienation, increased anxiety, spiritual devastation, cynicism, cruelty, manifestations of various forms of violence and aggression, rude treatment of others, decline in interest in education and community service, and so on are very common. The number of children with behavioral disorders and those who belong to the "risk group" is growing; the share of illegal, aggressive behavior of children and adolescents is increasing. Conflicts in the "student-student" and "student-teacher" system caused by violence are a serious destabilizing factor.

Research publications analysis. The problem of violence in the social environment began to be considered at the beginning of the $20^{\text {th }}$ century. The first studies on the problem of violence were conducted by Scandinavian and British scientists D. Olveus, E. Roland, P. Heinemann, D. Lane, W. Orton, D. Tattum, E. Munte and others. After the publication in 1960 by the Swedish physician P. Heinemann of the book "Mobbing - Gang Violence Among Children and Adults", the term "mobbing" was introduced into psychology, which is interpreted as a collective aggression aimed at a person who interfered with others to engage in their usual activities. Another Swedish researcher, $\mathrm{H}$. Leiman, defined "mobbing" as "psychological terror", that is, the systematic hostility of one person or several to another.

Norwegian psychologist D. Olveus on the basis of the concept "mobbing" introduced a new term - bullying, recognizing it as a special type of violence, "intentional, systematically repetitive aggressive behavior based on inequality of social power or physical force" (Olweus, 1978).

In Ukraine, bullying, as a psychological and pedagogical problem, has been considered relatively recently, and the existing problem of bullying in schools has simply been silenced. However, recently interest in this problem has declined. After all, today this antisocial phenomenon is very common in the school environment.

R. Ivanchenko, O. Ozhiyova, S. Bogomaz cover the causes of school bullying in their scientific works; I. Kuzmin and O. Kuznetsova study the problem of bullying in adolescence; scientific works by S. Muddy, T. Nalyvayko, I. Regush are devoted to methods of prevention and prevention of bullying in adolescence; K. Plutytska and others reveal approaches to understanding bullying as a form of school violence. 


\section{Інноватика у вихованні. Випуск 14. 2021.}

The research aims and objectives - to carry out a theoretical analysis of the concept of "bullying", to characterize the factors that contribute to the spread of bullying in the school environment and to outline areas for its prevention.

Presenting the main research material. In the Cambridge English Dictionary, the verb "to bully" is interpreted as "insulting or intimidating someone who is less or less influential than you" (Meaning of "bully" in the English Dictionary).

The Oxford Dictionary gives the following definition of "to bully": "the desire to harm, intimidate or coerce a vulnerable person or a person who is perceived as vulnerable" (Main definitions of bully in English).

According to I. Kon, bullying is intimidation, physical or psychological terror, aimed at causing fear in another and thus subordinating him to himself (Кон).

In our opinion, bullying is individual or group physical or psychological violence against a person who is unable to protect himself at that time. This is a form of cruel behavior when the physically or psychologically stronger (bully, abuser) gets pleasure from ridicule, bullying of the weaker (victim).

Buhler never regrets his actions and deeds. And a bully who is bullied, is not always able to tell others for fear of being heard, misunderstood, or even humiliated.

R. Ivanchenko, O. Ozhiyova, S. Bogomaz cover the factors of school bullying in their scientific works; I. Kuzmin and O. Kuznetsova study the problem of bullying in adolescence; scientific works of S. Muddy, T. Nalyvayko, I. Regush are devoted to the methods of prevention and prevention of bullying in adolescence; K. Plutytska reveals approaches to understanding bullying as a form of school violence.

According to G. Kozhukhar, bullying exists in the form of two behavioral subcategories: direct and indirect intimidation. Direct intimidation (active bullying) involves: threats, humiliation, insults, humiliation, harassment, causing trouble. Indirect intimidation (passive bullying) includes: spreading rumors, spoiling personal belongings, lying, damaging reputation, isolation (Кожухарь, 2012, p. 230-245).

Bullying, as a social phenomenon, is manifested among people of different ages, but most severely in adolescent groups. A teenager's sense of belonging to a certain group is essential for the development of his personality and the formation of behavior. Psychologists consider the desire to merge with a group as a mechanism of psychological protection and call it social mimicry.

A group for a teenager is a specific type of emotional contact that arises from meeting his need for affiliation; it is the carrier of a certain subculture; a necessary condition for identifying the position of the adolescent and gaining his status in it; this is the so-called free communication, which in most cases takes place outside the pedagogical influence. Group approval or condemnation of adolescent behavior by other members of the group is deeply felt, evokes feelings of elation or guilt. The teenager's desire to be the center of attention and look cool, the desire to establish the right to leadership or strengthen their status 


\section{Інноватика у вихованні. Випуск 14. 2021.}

in it leads to a struggle for power in the group, which in most cases occurs by demonstrating physical or emotional superiority over other group members.

This is noted in their studies Salmivalli, Koula, Juvonen, Galvan, Cillessen, Borch. Bullying allows the abuser to maintain a high status in the group for a long time, as there is a certain imbalance of forces between the abuser and the victim, which, in turn, forms and maintains the group structure (Salmivalli Ch. KiVA: the national anti-bullying program in Finland).

. Analysis of psychological and pedagogical literature allows us to identify a number of factors that contribute to the development and spread of bullying in adolescence: low socio-economic status of the family, family conflicts, changes in the family (stepfather, stepmother, second child, etc.), hyperopia or parental indifference; low school performance and inflated requirements for the success of the adolescent, which do not correspond to his abilities, capabilities; low level of education; inadequately underestimated self-esteem and a sense of selfpreservation; weak social skills and abilities of children, when they do not know how to agree, ask for help, share opinions or things that worry them, recognize their feelings and the condition of other children; high impulsivity; envy, revenge, feelings of hostility; self-affirmation through the humiliation of the victim, up to the satisfaction of their own sadistic needs; alcohol, drug and computer game abuse; personal aggression of the teenager, which depends on individual characteristics and conditions of upbringing; membership in the group and the desire to maintain their status in it; the struggle for power in the group, the desire and need to dominate others; life experience, which includes manifestations of aggression, hostility, violence, etc.

The development and spread of bullying in school is facilitated by the presence of a recognized informal "leader" in the classroom, lack of teacher control over student behavior during breaks, the emergence of acute conflict between two adolescents under the influence of external factors that provoke bullying, teachers' reluctance to interfere. internal clarification of issues in the classroom", deliberate concealment of bullying at school in order not "to take out the trash" from the classroom or school. That is, if teachers conceal the facts of the manifestation of this negative phenomenon, do not pay attention to the development of the student group, the students are presented to themselves and all the prerequisites for bullying are created as the basis of relationships in the classroom. At the same time, the "victim" constantly receives psychological trauma, and the bully develops a strong sense of impunity, permissiveness, omnipotence in relation to acts of violence, humiliation. However, we should not forget that the school is responsible for the development of the child's personality, for the quality of relationships in the system "teacher - student", "student - student".

Favorable for the bully is the insecurity of the victim, the unwillingness of the victim to defend himself and low self-esteem of the victim. It is important for the bully that the victim is weaker, unable to defend himself and has no protection and support from others. If no one responds to the violence, the bullying continues and becomes regular, systematic.

The victim's unwillingness to defend himself is associated with acknowledging the physical or emotional superiority of the bully, fear of feeling 


\section{Інноватика у вихованні. Випуск 14. 2021.}

even more aggressive and violent, and being "bad" in the eyes of parents because of the parents' attitude of "fighting is bad and surrendering". Everyone knows who is stronger and who is weaker in the class, so the weaker always gives way to the stronger, and the stronger always comes. Low self-esteem of the victim is associated with loneliness, social unhappiness, depression, inability to communicate with peers, developed inferiority complex, passive obedience. dissatisfaction with oneself "unties the hands" of the bully. Buller is also attracted by individual traits of a weaker character: timidity, anxiety, sensitivity, distrust, fear. And then the relationship in bullying is built on the rules of humiliation, force, persecution of the victim, withdrawal of aggression from themselves, etc.

Nowadays there are effective behavioral responses to bullying situations. First, the role of observer should not be taken, as the joining of observers to harassment forms a so-called "bullying circle" (Dan Olveus), which deepens bullying (harassment), reduces empathy for the victim under group pressure (suppression of empathy) and worsens the "victim's" condition..

For the formation of bullying (harassment) it is needed the approval or tacit support of the actions of the offender (buller) by others - observers (witnesses) (Tilikina, Holzberg, Melnichenko).

If the bully has no emotional or physical support, "no public", the situation may change for the better. Secondly, the situation of supporting the victim is important. Classmates can help a child who has been bullied to take his or her side, and if there is a majority, the abuser will eventually stop being aggressive towards the victim. Third, a person who has witnessed a bullying situation must be confident in their emotional and physical strength. After all, she must convince the bully to stop bullying, harassment, violence. Such behavior can be risky for the victim's defender, because if the offender has a large support group, then aggressive behavior can be directed at him. That is why such a behavioral response is used infrequently, although in some cases it is very effective.

There are five stages of bullying

1. Creating conditions. An interpersonal conflict or an unfavorable psychological climate in a group (team) due to high emotional tension can act as a precondition.

2. The initial stage. There is a search for the culprit, who is aggressively attacked in order to relieve and relieve emotional tension.

3. Active stage. This is a phase of systematic mockery of the victim, her harassment, regardless of her real actions and deeds.

4. Social isolation of the victim. At this stage, the object of bullying is partially or completely isolated from the team.

5. Escalation of the conflict. Most often, the victim is forced to leave the team because she is not accepted there (Евтихов, 2010).

To eliminate the manifestations of bullying in the classroom or school environment, it is necessary to establish or rebuild interpersonal relationships in the group, to make them trusting and positive. Therefore, important in the practical activities of the school is its psychological and pedagogical prevention, 


\section{Інноватика у вихованні. Випуск 14. 2021.}

which is implemented at the individual, group, school and family levels. It aims to preserve the mental health of children, as well as to create conditions in which the influence of factors that provoke violence, harassment, aggression, terror, etc. is minimized or eliminated.

Prevention is carried out by correcting existing social deviations. Psychological and pedagogical activities aimed at preventing and overcoming bullying are based on the principles of individuality, social adequacy, consistency and consistency, personal responsibility of the adult, self-reliance and potential personality, cognitive activity and independence, focus on the child's ability to overcome obstacles, security and protection of health, rights, human dignity, the principle of parallel action and technology.

To begin with it is necessary to carry out diagnostics at the level of group, class, school. The diagnostic stage of preventive work includes: diagnosis of the content of the activities of students, class teacher and class team.

Diagnosis will allow to determine the presence of aggressive, conformal, victim actions and deeds in behavior; identify the causes of such behavior; realize the nature of difficulties in interacting with others. Diagnostic methods: questionnaire, self-observation, self-analysis, self-report.

The result of the diagnosis is the establishment of socio-pedagogical diagnosis, on the basis of which the next stage of prevention is built, which is associated with the implementation of the bullying prevention program, which is implemented at four levels: school, group (class), personal and family.

Prevention of bullying at the school level: creating a favorable and safe environment for the development and socialization of the student's personality; improving the quality of interaction of all participants in the educational process; assessment of psychological comfort and safety of the educational environment at school; creation and support of effective work of the school mediation service (reconciliation), the work of which is based on the use of restorative technologies in the educational process; involvement of students in the work of the mediation service (reconciliation), including through the formation and training of "peer groups", providing supervision and assistance to "peer groups"; increasing the competence of teachers in the prevention of bullying and cohesion of class groups; development of anti-bullying rules at school and implementation of $\mathrm{kg}$ of trolls for their observance; maintaining high prosocial activity of students (their educational and extracurricular interests, clubs, hobbies, sports); ensuring that any of the school staff intervenes in the harassment situation as soon as it is noticed.

At the group level (class team) the following areas of prevention are implemented: diagnosis of interpersonal relationships in the classroom to identify cases of bullying; Organizing the "circle of community" as a way of positive socialization, which allows you to gain experience in participation in decision-making, active life position, respectful and sensitive attitude to the needs of others; implementation of prevention programs aimed at uniting class groups, reducing competition and teaching children the skills of "active friendship": 1) respect each other and treat others as equals; 2) rejoice in the 


\section{Інноватика у вихованні. Випуск 14. 2021.}

success of others; 3) accept the value of each team member; 4) be able to communicate positively; 6) resolve and resolve conflict situations.

If in primary school the training of these skills can be provided during the game, during breaks, after lessons in sports, then in the middle grades you should use mentoring or counseling with the involvement of high school students.

In this situation it is important a pedagogical support, based on the individualization of educational activities focused on the situation "here and now", providing assistance for adolescents to overcome the influence of individual and group factors that cause bullying in the classroom and school; class team development; humanization of interpersonal relationships; understanding the mental predisposition of children to inappropriate behavior; identification of features of regulation of motivational, emotional, volitional and moral state of children capable of violation of discipline, antisocial behavior. Pedagogical support allows to prevent bullying and create conditions for selfrealization of group members in joint group activities.

At the personal level, the following areas of prevention are implemented: psycho-correctional work with students who show aggression and violence; psycho-correctional work with students with manifestations of victim behavior; conducting mediation procedures and other restorative technologies with those who are being harassed and those who are being harassed; development and implementation of individual prevention programs.

At the family level, the following areas of prevention are implemented: educational work with parents in order to form their position on stopping bullying; targeted informational and educational work with parents; organization of meetings with parents of children involved in school bullying; consultations and trainings on parenting styles, family conflicts, psychological characteristics of children of different ages. It is effective to develop a memo for parents, which to some extent answers the questions: $\square$ what to do if a child is bullied; what to do if it became known about a case of bullying in the classroom, group, where your child is an observer; what to do if the child is a provocateur of bullying, etc.

Conclusions and further research prospects. Prevention of bullying is urgent because it aims to reduce aggression, violence, harassment, humiliation among adolescents and the prevention of juvenile delinquency. It should be held at all levels. Therefore, these aspects highlight the need for further in-depth study of the problem of psychological and pedagogical prevention, the allocation of productive techniques and techniques to prevent this phenomenon.

\section{REFERENCES}

Bulinh (tskuvannia) yak yavyshche, yoho formy ta uchasnyky [Bullying as a phenomenon, its forms and participants] // Avt. kol.: Tilikina N.V., Holtsberh K.O., Melnychenko A.A. URL: https: //nupp.edu.ua/uploads/files/0/main/deps/ps/buling/module1/buling-iak-iavische.pdf [Data zvernennia 7.05.2021]. [in Ukrainian]

Evtikhov, O. (2010). Mobbing: fazy razvitiya i ego profilaktika. [Mobbing: developmental phases and its prevention]. M. 319 s. [in Russian] 


\section{Інноватика у вихованні. Випуск 14. 2021.}

Kon, Y. Chto takoe bulling i kak s nim borotsya? [What is bullying and how to deal with it?] / I.S. Kon. // Seksologiya. Personalnyi sait I.S.Kona. URL: http://www.sexology.narod.ru/info178.html. [Data zvernennia 12.09.2021]. [in Russian]

Kozhukhar, G. (2012). Fenomenologiya raznykh form psikhologicheskogo nasiliya $\mathrm{v}$ molodezhnoy srede: zarubezhnyie issledovaniya [Phenomenology of different forms of psychological violence in the youth environment: foreign studies] // Psikhologicheskaya nauka i obrazovaniye. URL: www.psyedu.ru. No 2. - S. 230-245. [Data zvernennia 12.09.2021]. [in Russian]

Main definitions of bully in English: URL: https:enoxforddictionaries.com/definition/bully [Data zvernennia 12.09.21]. [in English]

Meaning of "bully" in the English Dictionary. URL: https: dictionary.cambridge,org/dictionary/english/bully?q=bullying\#translation [Data zvernennia 17.09.2021]. [in English]

Olweus, D. (1978). Aggression in the schools: Bullies and whipping boys. Oxford, England: Hemisphere, 218 p. [Data zvernennia 12.09.2021]. [in English]

Olweus, D. (1993). Bulling at school: what we know what we can do. Olweus D. Malden, M. A. Blackwell Publishing. URL: http:onlinelibrary.wiley.com/doi/10.1002/pits.10114/abstract [Data zvernennia 7.06.2021]. [in English]

Salmivalli Ch. KiVA: the national anti-bullying program in Finland: URL: http://www.ncab.org.au/Assets/Files/Salmivalli,C.\%20Kiva\%20Koula\%20-\%20The\% 20National\%20Antibullying\%20Program\%20in\%20Finland.pdf. [Data zvernennia 05.04.2021]. [in English]

\section{СПИСОК ВИКОРИСТАНИХ ДЖЕРЕЛ}

Булінг (цькування) як явище, його форми та учасники. // Авт. кол.: Тілікіна H.В., Гольцберг К.О., Мельниченко А.A. URL: https: //nupp.edu.ua/uploads/files/0/main/deps/ps/buling/module1/buling-iak-iavische.pdf [Дата звернення 7.05.2021].

Евтихов, О. (2010). Моббинг: фазы развития и его профилактика. М. 319 с.

Кон, И. Что такое буллинг и как с ним бороться? / И.С. Кон. // Сексология. Персональный сайт И.С.Кона. URL: http://www.sexology.narod.ru/info178.html. [Дата звернення 12.09.2021].

Кожухарь, Г. (2012). Феноменология разных форм психологического насилия 6 молодежной среде: зарубежные исследования // Психологическая наука и образование. URL: www.psyedu.ru. № 2. - С. 230-245. [Дата звернення 12.09.21].

Main definitions of bully in English: URL: https:enoxforddictionaries.com/definition/bully [Дата звернення 12.09.2021].

Meaning of "bully" in the English Dictionary. URL: https: dictionary.cambridge,org/dictionary/english/bully?q=bullying\#translation [Дата звернення 17.09.21].

Olweus, D. (1978). Aggression in the schools: Bullies and whipping boys. Oxford, England: Hemisphere, 218 р. [Дата звернення 12.09.2021].

Olweus, D. (1993). Bulling at school: what we know what we can do. Olweus D. - Malden, M. A. Blackwell Publishing. URL: http:onlinelibrary.wiley.com/doi/10.1002/pits.10114/abstract [Дата звернення 7.06.2021].

Salmivalli Ch. KiVA: the national anti-bullying program in Finland: URL: http://www.ncab.org.au/Assets/Files/Salmivalli,C.\%20Kiva\%20Koula\%20-\%20The\% 20National\%20Antibullying\%20Program\%20in\%20Finland.pdf. [Дата звернення 05.04.2021] 


\section{Інноватика у вихованні. Випуск 14. 2021.}

\section{ПСИХОЛОГО-ПЕДАГОГІЧНА ПРОФІЛАКТИКА БУЛІНГУ В ШКІЛЬНОМУ СЕРЕДОВИЩІ}

\section{Ціпан Тетяна}

кандидат педагогічних наук, доцент, доцент кафедри теорії і методики виховання Рівненського державного гуманітарного університету, м. Рівне, Україна ORCID: 0000-0002-1356-2825 e-mail:23ttss22@ukr.net

Анотація. У статті здійснено аналіз поняття «булінг» та схарактеризовано напрями психолого-педагогічної профілактики цього явища. Булінг розглядається як індивідуальне або групове фізичне чи психологічне насильство над особою, яка не здатна захистити себе на момент здійснення насильства над нею; як форма жорстокої поведінки, коли фізично або психологічно сильніший (булер, кривдник) отримує задоволення від насмішок, знущань над слабшим (жертвою). Вирізнено чинники та причини поширення боулінгу у шкільному середовищі.

3'ясовано, що булінг існує в формі двох поведінкових підкатегорій: прямого і непрямого залякування. Пряме залякування (активний булінг): загрози, приниження, образи, приниження, переслідування, заподіяння неприємностей; непряме залякування (пасивний булінг): поширення чуток, псування особистих речей, оббріхування, нанесення шкоди репутації, ізоляція. Проаналізовано п’ять стадій боулінгу: створення умов, початкова стадія, активна стадія, соціальна ізоляція жертви, ескалація конфлікту.

Схарактеризовано напрями психолого-педагогічноъ профілактики булінгу, що реалізується на особистісному, груповому, загальношкільному та сімейному рівнях, яка спрямована на збереження на зміцнення психічного здоров'я школярів, а також створення умов, за яких максимально знижується або нівелюється вплив чинників, що провокують насилля, цькування, агресію, терор тощо.

Ключові слова: булінг, цькування, школярі, діагностика, психологопедагогічна профілактика.

Стаття надійшла до редакиіï 14.09.2021p. 